\title{
Typicity in Potato: Characterization of Geographic Origin
}

\author{
Marco Manzelli*, Sigfrido Romagnoli, Lisetta Ghiselli, Stefano Benedettelli, \\ Enrico Palchetti, Luisa Andrenelli, Vincenzo Vecchio \\ Department of Agronomy and Land Management, University of Florence \\ Piazzale delle Cascine 18, 50144 Florence, Italy
}

Received: 14 September 2009. Accepted: 10 November 2009.

\begin{abstract}
A two-year study was carried out in three regions of Italy and the crop performance and the chemical composition of tubers of three typical potato varieties evaluated. Carbon and nitrogen tuber content was determined by means of an elemental analyzer and the other mineral elements by means of a spectrometer. The same determinations were performed on soil samples taken from experimental areas. The Principal Component Analysis, applied to the results of mineral element tuber analysis, permitted the classification of all potato tuber samples according to their geographic origin. Only a partial discrimination was obtained in function of potato varieties. Some correlations between mineral content in the tubers and in the soil were also detected. Analytical and statistical methods proved to be useful in verifying the authenticity of guaranteed geographical food denominations.
\end{abstract}

Key-words: Food authenticity, geographical denomination, mineral elements, potato, Principal Component Analysis.

\section{Introduction}

Typical food products have an important economical role both on a National and International level, as is confirmed by the several certifications and trademarks of quality (e.g. Protected Denomination of Origin, PDO and Protected Geographical Identification, PGI) assigned to guarantee their typicity and quality standards. Italy accounts for the greatest number of typical food products (113 PDO and 61 PGI) in the European Union (456 PDO and 361 PGI), and has more than 4000 traditional food products. As mentioned above, Italy has a wide reserve of typical food productions, that, together with the food products already certified, may contribute to the economical development of small rural areas, thereby also promoting innovation processes.

In reference to potato cultivation, two principle typologies of production are evident in Italy: in the North of Italy potato is normally grown in the spring-summer period, while in the South potato is typically grown as an extra-seasonal crop (early or late potato). The latter pro- duction occupies an important niche, especially in the foreign markets, resulting in raised prices which are higher than those of seasonal potatoes. This production is usually based on commercial potato varieties, selected in Germany or The Netherlands, even though traditional varieties are cultivated in some rural areas.

National potato production is generally carried out in small agricultural areas, each with typical characteristics in terms of pedo-climatic conditions and cultivated varieties. For that reason, farmer associations belonging to those areas presented several PDO and PGI requests to the European Union. Of the seasonal potato products, the Typical Potato of Bologna is actually under the national food quality protection awaiting the European PDO certification, while the Potato of Sila (Calabria) has temporarily obtained the PGI. Other typical potato growing areas are located in different Italian regions, such as Liguria, Toscana and Abruzzo. Regarding extra-seasonal potato production, the most important areas are located in the Province of Lecce (Puglia) and in the Province of Siracusa (Sicilia). 
Potatoes obtained in those areas usually have high quality standards fetching good prices on national and international markets. However their cost of production is usually higher than those registered in the countries of North Europe. As a consequence, there is the possibility that potatoes produced at lower costs are sold illegally as typical Italian food products. In this context, the typicity of local food production, which characteristics are linked to specific pedo-climatic conditions and unique cultivars, must be also guaranteed by the definition of appropriate methods and analytical techniques.

Today, the genetic characterization of vegetal species can be obtained by means of molecular markers such as the microsatellites SSR (Coombs et al., 2004; Ghislain et al., 2004; Feingold et al., 2005; Moisan-Thiery et al., 2005). For some years, some analytical methods have been available to determine the geographic origin of food products, such as those based on the analysis of organic compounds as aminoacids (Airesde-Sousa, 1996), vitamins and pro-vitamins (Ferland and Sadowski, 1992), fats and free fat acids (Parcerisa et al., 1994), all of which provide a high percentage of correct classification (70$90 \%)$. However, the content of organic substances in potato can significantly change during storage. For this reason, the chemical methods based on elemental mineral content are preferred for food products like potatoes, as has been confirmed by recent studies. Potatoes (variety Kennebec) grown in Galicia (Spain), following a specific production itinerary, were characterized in terms of mineral content by means of a Flame Atomic Emission Spectrometer (FAES) and a Flame Atomic Absorption Spectrometer (FAAS). The classification of samples by means of the neural network method permitted the correct classification of about $98 \%$ of samples discriminating between the products obtained with local or conventional crop management (Padín et al., 2001). In the United States of America, elemental analysis was utilized, by means of an Inductively Coupled Plasma Spectrometer (ICP-OES), to verify the geographic origin of potatoes grown in the State of Idaho compared to other potatoes of different origins (Anderson et al., 1999). Discriminant analysis was able to separate the potatoes from Idaho ( $97 \%$ of correct classification) and the potatoes from other growing areas
(95\% of correct classification). Applying the neural network method, about the $99 \%$ of samples were correctly classified. Recently, Di Giacomo et al. (2007) verified the possibility of being able to geographically discriminate between potatoes grown in the Fucino basin and potatoes derived from other Italian growing areas through the application of spectrometer elemental mineral analysis. The application of multivariate statistical analysis permitted the correct classification of more than $90 \%$ of the tuber samples analyzed.

The main objective of this study, inserted in the project "Environment, genotype and typicality in potato and artichoke" financed by MIUR (Ministero dell'Istruzione, dell'Università e della Ricerca), was to characterize, in function of their tuber elemental mineral content, three typical Italian potato productions according to their geographic and varietal origin in order to understand to what extent the typicity of those productions was linked to environment and/or to genotype.

\section{Material and methods}

\section{Locality, plant material and tuber sampling}

In the years 2005 and 2006, three experimental trials were implemented in three Italian potato areas, Ugento (Puglia), Cassibile (Sicilia) and Cetica (Toscana), by growing three typical potato varieties, respectively Sieglinde, Arinda and Rossa di Cetica. Those varieties are widely cultivated in the above mentioned localities, covering the great part of local potato production. The morphological and technological characteristics of the above mentioned varieties are reported in Table 1. In Puglia and Sicilia, the potato areas are close to the sea and the potatoes are typically sown early (December-January) and harvested during the period of March-June. In Tuscany, the potato area is between $500-1000$ $\mathrm{m}$ a.s.l., and the cropping cycle is during the period of May-September. The experimental trials were conducted by growing the three varieties in all the selected areas in order to discriminate between the genotypic and the environmental effects. Each experimental field was organized according with randomized block design with four blocks. Each plot had an area of about 20 $\mathrm{m}^{2}$, with a plant density of 6 plant $\mathrm{m}^{-2}$. Before 
Table 1. Main morphological and technological characteristics of potato varieties.

\begin{tabular}{llll}
\hline & Sieglinde & Arinda & Rossa di Cetica \\
\hline Tuber size & Small & Big & Medium \\
Tuber shape & Oval & Oval-elongated & Round with deep buds \\
Skin color & Yellow & Yellow & Intense red \\
Pulp color & Intense yellow & Light yellow & White with red spots \\
Pulp consistence & Very compact & Compact & Compact \\
Dry matter content & Medium & Low & High \\
\hline
\end{tabular}

sowing, soil samples from each area were collected. Every year in the three areas, tuber samples of about $1 \mathrm{~kg}$ (10-15 tubers) were collected from each plot. After washing in deionised water, tuber samples were firstly subdivided between pulp and peel, and then frozen in liquid nitrogen, lyophilized and milled. Macro and microelements analysis was performed on lyophilized samples, previously dried at $105{ }^{\circ} \mathrm{C}$, by means of a CHN elemental analyzer (Thermo Fisher Scientific Waltham, Massachusetts, USA) and an inductively coupled plasma spectrometer (ICP-OES IRIS Intrepid II XSP Radial, Thermo Fisher Scientific, Waltham, Massachusetts, USA).

\section{Soil samples}

For each year of experimentation, five soil samples per plot were collected at a depth of 0-30 $\mathrm{cm}$. Samples from each plot were homogenized, dried at $40{ }^{\circ} \mathrm{C}$ for three days and milled. Macro and microelements analysis was performed on soil samples according to that performed on the tuber samples.

\section{Analytical methods}

For potato samples, carbon and nitrogen determinations were performed using 3-4 mg of vegetal material. Macro and microelement analysis was performed using $0.5 \mathrm{mg}$ of vegetal material. This share of samples was mineralized in a Teflon becker containing $5 \mathrm{ml}$ of nitric acid $(67 \%)$ and $5 \mathrm{ml}$ of deionised water $18 \mathrm{M} \Omega$. At the end of the mineralization, the final volume of the solution was obtaining by adding $25 \mathrm{ml}$ of water $18 \mathrm{M} \Omega$.

Macro and microelement analysis of soil samples was preceded by $\mathrm{pH}$ determination, according to the Italian official soil chemical analysis (Ordinary Supplement to Gazzetta Ufficiale n. 248 of 21/10/1999). Carbon and nitrogen determinations were analyzed on $25 \mathrm{mg}$ soil samples. Soluble salts were determined after ex- traction in water, according to the above mentioned methods. Exchangeable cations ( $\mathrm{Na}, \mathrm{K}$, $\mathrm{Mg}, \mathrm{Ca}$ and those with a similar chemical behavior, $\mathrm{Sr}$ and $\mathrm{Ba}$ ) were determined after extraction in ammonium acetate at $\mathrm{pH}$ 7. This type of extraction was also used for the non metallic elements ( $\mathrm{B}$ and $\mathrm{P}$ ) adding metallic cations $\left(\mathrm{Na}^{+}\right)$and for Mo that is normally present in the soil as anionic form $\left(\mathrm{MoO}_{4}{ }^{2-}\right)$. For the remaining metallic elements $(\mathrm{Al}, \mathrm{Co}, \mathrm{Cr}, \mathrm{Cu}, \mathrm{Fe}, \mathrm{Mn}$, $\mathrm{Ni}, \mathrm{Pb}, \mathrm{V}, \mathrm{Zn}$ ), their availability was determined after extraction with complexants (EDTA Ethylenediaminetetraacetic acid or Diethylklenetriaminepentacetic acid DTPA).

\section{Statistical analysis}

The results were analyzed statistically by means of the software SYSTAT 9.1 for Windows, version 1999 (SPSS Inc., Chicago, Illinois, USA). A total of 80 variables derived from tuber and soil samples were inserted in the analysis. ANOVA was performed according to the fixed factor model, considering as sources of variation, year, locality, cultivar (only for potato samples) and their interactions. The weight of each source of variation on the total sum of squared was evaluated in function of its determination coefficient. A multivariate analysis (Principal Component Analysis - PCA) was performed on the variables and the results represented in $3 \mathrm{D}$ graphs in order to detect homogenous groups per cultivar and/or environment.

\section{Results}

\section{Macro and microelements in the tubers}

Eighteen mineral elements (Al, B, Ba, Ca, Cd, $\mathrm{Co}, \mathrm{Cr}, \mathrm{Cu}, \mathrm{Fe}, \mathrm{K}, \mathrm{Mg}, \mathrm{Mn}, \mathrm{Na}, \mathrm{Ni}, \mathrm{P}, \mathrm{Sr}, \mathrm{V}, \mathrm{Zn}$ ) were detected in tuber samples. For tuber pulp samples, ANOVA showed significant differences between localities, except for $\mathrm{Al}, \mathrm{Cd}$ and $\mathrm{Co}$ 
Table 2. Average tuber fresh weight (g), carbon and nitrogen content (\% on dry matter) and mineral element content $(\mathrm{mg} / \mathrm{kg}$ on dry matter) in tuber pulp samples for year, locality and cultivar (different letter for each variable and source of variation indicate significant difference at $\mathrm{p}<0.05)$.

\begin{tabular}{lcrrrrrrr}
\hline & Year & & Locality & Cultivar & & & Tuber weight \\
& 2006 & 2007 & & & & \\
\hline & & & Ugento & Cassibile & Cetica & Arinda & Rossa di Cetica & Sieglinde \\
$\mathrm{C}$ & $83.5 \mathrm{a}$ & $97.6 \mathrm{a}$ & $86.7 \mathrm{ab}$ & $103.1 \mathrm{a}$ & $81.7 \mathrm{~b}$ & $117.6 \mathrm{a}$ & $91.8 \mathrm{~b}$ & $62.2 \mathrm{c}$ \\
$\mathrm{N}$ & $43.8 \mathrm{a}$ & $42.9 \mathrm{~b}$ & $43.5 \mathrm{a}$ & $43.5 \mathrm{a}$ & $43.1 \mathrm{~b}$ & $43.3 \mathrm{a}$ & $43.3 \mathrm{a}$ & $43.4 \mathrm{a}$ \\
$\mathrm{Al}$ & $2.1 \mathrm{a}$ & $2.2 \mathrm{a}$ & $2.2 \mathrm{a}$ & $2.1 \mathrm{~b}$ & $2.2 \mathrm{ab}$ & $2.2 \mathrm{a}$ & $2.2 \mathrm{a}$ & $2.2 \mathrm{a}$ \\
$\mathrm{B}$ & $1.1 \mathrm{~b}$ & $1.9 \mathrm{a}$ & $1.7 \mathrm{a}$ & $1.5 \mathrm{a}$ & $1.3 \mathrm{a}$ & $1.3 \mathrm{a}$ & $1.4 \mathrm{a}$ & $1.7 \mathrm{a}$ \\
$\mathrm{Ba}$ & $4.6 \mathrm{~b}$ & $4.9 \mathrm{a}$ & $4.6 \mathrm{~b}$ & $4.9 \mathrm{a}$ & $4.7 \mathrm{~b}$ & $4.8 \mathrm{~b}$ & $5.1 \mathrm{a}$ & $4.3 \mathrm{c}$ \\
$\mathrm{Ca}$ & $0.9 \mathrm{a}$ & $0.6 \mathrm{~b}$ & $0.6 \mathrm{~b}$ & $0.3 \mathrm{c}$ & $1.3 \mathrm{a}$ & $0.6 \mathrm{~b}$ & $0.9 \mathrm{a}$ & $0.8 \mathrm{ab}$ \\
$\mathrm{Cd}$ & $215.3 \mathrm{a}$ & $168.6 \mathrm{~b}$ & $232.9 \mathrm{a}$ & $207.0 \mathrm{~b}$ & $136.0 \mathrm{c}$ & $175.8 \mathrm{~b}$ & $203.8 \mathrm{a}$ & $196.3 \mathrm{ab}$ \\
$\mathrm{Co}$ & $0.1 \mathrm{a}$ & $0.1 \mathrm{~b}$ & $0.1 \mathrm{a}$ & $0.1 \mathrm{a}$ & $0.1 \mathrm{a}$ & $0.1 \mathrm{a}$ & $0.1 \mathrm{a}$ & $0.1 \mathrm{a}$ \\
$\mathrm{Cr}$ & $0.1 \mathrm{a}$ & $0.0 \mathrm{a}$ & $0.1 \mathrm{a}$ & $0.0 \mathrm{a}$ & $0.1 \mathrm{a}$ & $0.0 \mathrm{a}$ & $0.1 \mathrm{a}$ & $0.1 \mathrm{a}$ \\
$\mathrm{Cu}$ & $0.1 \mathrm{~b}$ & $0.1 \mathrm{a}$ & $0.1 \mathrm{~b}$ & $0.1 \mathrm{~b}$ & $0.1 \mathrm{a}$ & $0.1 \mathrm{a}$ & $0.1 \mathrm{a}$ & $0.1 \mathrm{a}$ \\
$\mathrm{Fe}$ & $7.2 \mathrm{a}$ & $6.9 \mathrm{a}$ & $5.6 \mathrm{c}$ & $6.8 \mathrm{~b}$ & $8.6 \mathrm{a}$ & $7.0 \mathrm{~b}$ & $7.7 \mathrm{a}$ & $6.4 \mathrm{c}$ \\
$\mathrm{K}$ & $19.9 \mathrm{a}$ & $20.7 \mathrm{a}$ & $23.1 \mathrm{a}$ & $16.8 \mathrm{~b}$ & $20.9 \mathrm{a}$ & $18.4 \mathrm{~b}$ & $23.5 \mathrm{a}$ & $18.9 \mathrm{~b}$ \\
$\mathrm{Mg}$ & $1093 \mathrm{a}$ & $19235 \mathrm{a}$ & $21352 \mathrm{a}$ & $19468 \mathrm{~b}$ & $17437 \mathrm{c}$ & $19412 \mathrm{a}$ & $19998 \mathrm{a}$ & $18848 \mathrm{a}$ \\
$\mathrm{Mn}$ & $7.3 \mathrm{~b}$ & $8.2 \mathrm{a}$ & $7.8 \mathrm{a}$ & $7.1 \mathrm{~b}$ & $8.3 \mathrm{a}$ & $7.4 \mathrm{ab}$ & $7.3 \mathrm{~b}$ & $1227 \mathrm{a}$ \\
$\mathrm{Na}$ & $52.0 \mathrm{a}$ & $61.9 \mathrm{a}$ & $106.9 \mathrm{a}$ & $47.6 \mathrm{~b}$ & $16.2 \mathrm{c}$ & $52.1 \mathrm{a}$ & $64.2 \mathrm{a}$ & $5.5 \mathrm{a}$ \\
$\mathrm{Ni}$ & $0.7 \mathrm{a}$ & $0.6 \mathrm{a}$ & $0.6 \mathrm{~b}$ & $0.1 \mathrm{c}$ & $1.2 \mathrm{a}$ & $0.6 \mathrm{a}$ & $0.6 \mathrm{a}$ & $0.7 \mathrm{a}$ \\
$\mathrm{P}$ & $2834 \mathrm{a}$ & $2394 \mathrm{~b}$ & $2982 \mathrm{a}$ & $2232 \mathrm{c}$ & $2628 \mathrm{~b}$ & $2562 \mathrm{ab}$ & $2547 \mathrm{~b}$ & $2733 \mathrm{a}$ \\
$\mathrm{Sr}$ & $0.9 \mathrm{a}$ & $0.5 \mathrm{~b}$ & $0.6 \mathrm{~b}$ & $1.0 \mathrm{a}$ & $0.4 \mathrm{c}$ & $0.6 \mathrm{~b}$ & $0.7 \mathrm{ab}$ & $0.7 \mathrm{a}$ \\
$\mathrm{V}$ & $4.0 \mathrm{a}$ & $3.5 \mathrm{~b}$ & $3.6 \mathrm{~b}$ & $3.8 \mathrm{a}$ & $3.8 \mathrm{a}$ & $3.7 \mathrm{ab}$ & $3.6 \mathrm{~b}$ & $3.9 \mathrm{a}$ \\
$\mathrm{Zn}$ & $18.0 \mathrm{a}$ & $18.6 \mathrm{a}$ & $13.7 \mathrm{c}$ & $19.1 \mathrm{~b}$ & $22.2 \mathrm{a}$ & $16.4 \mathrm{c}$ & $20.5 \mathrm{a}$ & $18.1 \mathrm{~b}$ \\
\hline & & & & & & $1133 \mathrm{~b}$ &
\end{tabular}

(Tab. 2). Significant differences between cultivars were detected for $\mathrm{B}, \mathrm{Ba}, \mathrm{Ca}, \mathrm{Cd}, \mathrm{Cu}, \mathrm{Fe}$, $\mathrm{Mg}, \mathrm{Mn}, \mathrm{P}, \mathrm{Sr}, \mathrm{V}$ and $\mathrm{Zn}$ (Tab. 2). Regarding the elements more discriminant for localities $(\mathrm{Ba}$, $\mathrm{Ca}, \mathrm{Cu}, \mathrm{Fe}, \mathrm{K}, \mathrm{Na}, \mathrm{Ni}, \mathrm{P}, \mathrm{Sr}, \mathrm{Zn}$ ), the PCA permitted a clear distinction between the groups of samples derived from the three localities (Fig. $1)$. On the contrary, the separation between the

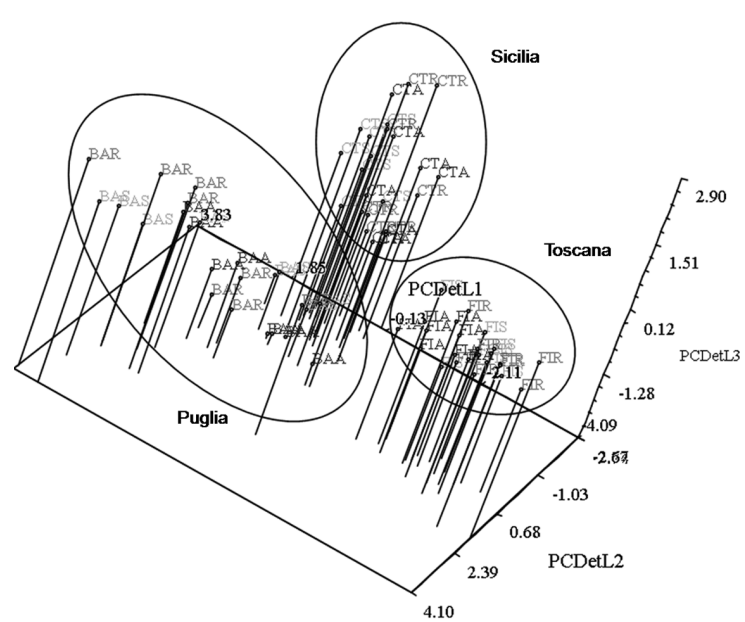

Figure 1. 3D visualization of PCA analysis for the variables more discriminant for locality. $(\mathrm{A}=\mathrm{Arinda}, \mathrm{R}=$ Rossa di Cetica, $\mathrm{S}=$ Sieglinde). groups belonging to the cultivars was not so clear. However, performing the PCA for each locality and considering only the elements more discriminant for cultivars $(\mathrm{B}, \mathrm{Cd}, \mathrm{Cu}, \mathrm{Fe}, \mathrm{Mn}, \mathrm{V}$, $\mathrm{Zn}$ ), it was possible to discriminate between the cultivars. The 3D graphs showed a clear separation between cultivars for the samples collected in Sicilia (Fig. 2), a partial separation be-

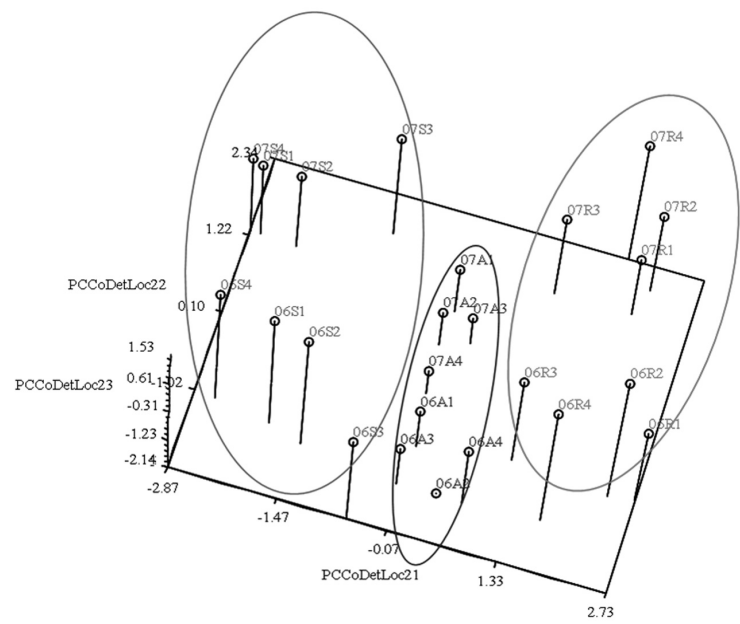

Figure 2.3D visualization of PCA analysis for the variables more discriminant for cultivar in the area of Cassibile (Sicilia). ( $\mathrm{A}=$ Arinda, $\mathrm{R}=$ Rossa di Cetica, $\mathrm{S}=$ Sieglinde $)$. 


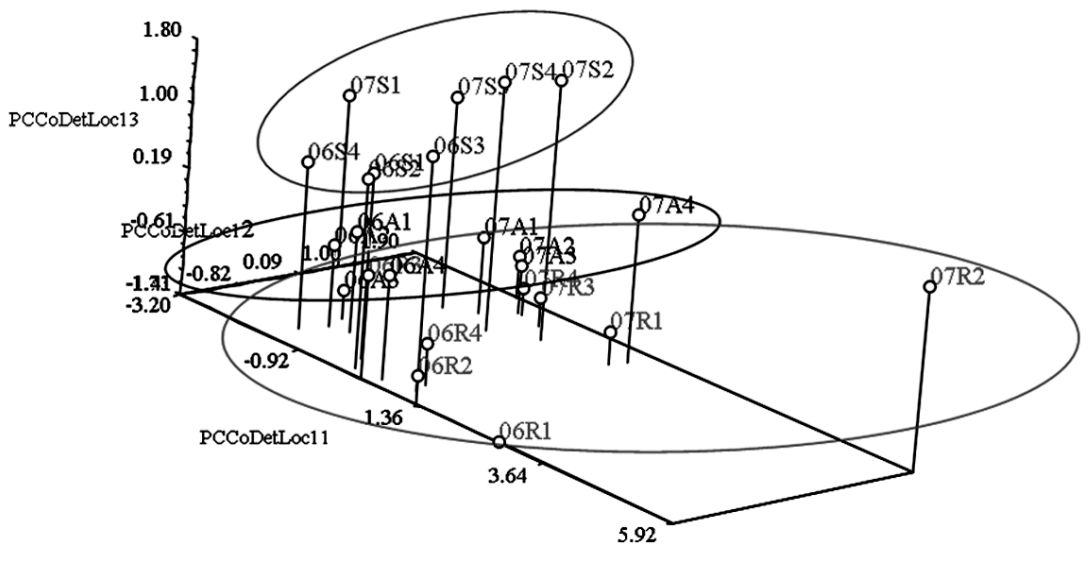

Figure 3. 3D visualization of PCA analysis for the variables more discriminant for cultivar in the area of Ugento (Puglia). ( $\mathrm{A}=$ Arinda, $\mathrm{R}=$ Rossa di Cetica, $\mathrm{S}=$ Sieglinde). tween Rossa di Cetica and Arinda for the samples collected in Puglia (Fig. 3), and a partial separation between Arinda and Sieglinde for the samples collected in Toscana (Fig. 4).

\section{Macro and microelements in the soil}

The results highlighted significant differences between localities $(p<0.01)$ for all the mineral elements and for the different extraction methods, except for $\mathrm{Cd}$ and $\mathrm{Mn}$ extracted with water $(\mathrm{p}<0.05)$ and Co extracted with water (not significant). However, the latter mineral elements were present in low concentration, close to the detection limits of the analytical methodology used (Tab. 3).

Soil samples showed clear differences in terms of $\mathrm{pH}$. Cetica, Ugento and Cassibile soils can be classified, respectively, as acid, sub-acid and basic soils. However, according to crop adaptation, the range of $\mathrm{pH}$ observed did not negatively affect the crop in any phase of the cycle.

In general, it was possible to observe that the chemical-physical characteristics of the experimental soils yielded a higher availability of exchangeable cations $(\mathrm{Na}, \mathrm{K}, \mathrm{Mg}, \mathrm{Ca})$ and non

Table 3. $\mathrm{pH}$ and mineral element content $(\mathrm{mg} / \mathrm{kg})$ in soil samples. Extraction solutions: ammonium acetate = (1), EDTA or DTPA complexant $=(2)($ Different letter for each variable and source of variation indicate significant difference at $\mathrm{p}$ $<0.05)$.

\begin{tabular}{|c|c|c|c|c|c|}
\hline & \multicolumn{3}{|c|}{ Year } & \multicolumn{2}{|l|}{ Locality } \\
\hline & 2006 & 2007 & Puglia & Sicilia & Toscana \\
\hline $\mathrm{pH}$ & $6.8 \mathrm{a}$ & $6.3 \mathrm{~b}$ & $6.5 \mathrm{~b}$ & $8.1 \mathrm{a}$ & $5.0 \mathrm{c}$ \\
\hline Al (2) & $176.2 \mathrm{~b}$ & $228.1 \mathrm{a}$ & $181.8 \mathrm{~b}$ & $0.1 \mathrm{c}$ & $424.6 \mathrm{a}$ \\
\hline B (1) & $0.4 \mathrm{a}$ & $0.3 \mathrm{~b}$ & $0.2 \mathrm{c}$ & $0.5 \mathrm{a}$ & $0.3 \mathrm{~b}$ \\
\hline $\mathrm{Ba}(1)$ & $33.5 \mathrm{~b}$ & $36.0 \mathrm{a}$ & $35.2 \mathrm{~b}$ & $50.6 \mathrm{a}$ & $18.5 \mathrm{c}$ \\
\hline $\mathrm{Ca}(1)$ & $4557 \mathrm{a}$ & $4411 \mathrm{~b}$ & $2572 \mathrm{~b}$ & 10415 a & $466 \mathrm{c}$ \\
\hline $\mathrm{Cd}(2)$ & $0.1 \mathrm{a}$ & $0.1 \mathrm{~b}$ & $0.1 \mathrm{a}$ & $0.1 \mathrm{~b}$ & $0.0 \mathrm{c}$ \\
\hline Co (2) & $1.9 \mathrm{a}$ & $1.7 \mathrm{~b}$ & $4.4 \mathrm{a}$ & $0.2 \mathrm{c}$ & $0.8 \mathrm{~b}$ \\
\hline $\mathrm{Cr}(2)$ & $0.3 \mathrm{~b}$ & $0.3 \mathrm{a}$ & $0.2 \mathrm{~b}$ & $0.0 \mathrm{c}$ & $0.7 \mathrm{a}$ \\
\hline $\mathrm{Cu}(2)$ & $4.0 \mathrm{a}$ & $8.1 \mathrm{a}$ & $11.2 \mathrm{a}$ & $4.4 \mathrm{~b}$ & $2.4 \mathrm{c}$ \\
\hline $\mathrm{Fe}(2)$ & $98.6 \mathrm{a}$ & $92.9 \mathrm{a}$ & $92.1 \mathrm{~b}$ & $8.1 \mathrm{c}$ & $187.1 \mathrm{a}$ \\
\hline K (1) & $396.5 \mathrm{~b}$ & $480.3 \mathrm{a}$ & $616.6 \mathrm{a}$ & $633.1 \mathrm{a}$ & $65.5 \mathrm{~b}$ \\
\hline $\mathrm{Mg}(1)$ & 386.6 a & $415.1 \mathrm{a}$ & $397.6 \mathrm{~b}$ & $725.1 \mathrm{a}$ & $79.7 \mathrm{c}$ \\
\hline Mn (2) & $122.4 \mathrm{a}$ & $115.6 \mathrm{a}$ & $282.8 \mathrm{a}$ & $18.5 \mathrm{c}$ & $55.6 \mathrm{~b}$ \\
\hline $\mathrm{Na}(1)$ & $47.0 \mathrm{~b}$ & $96.3 \mathrm{a}$ & $92.4 \mathrm{~b}$ & $113.4 \mathrm{a}$ & $9.2 \mathrm{c}$ \\
\hline $\mathrm{Ni}(2)$ & $1.6 \mathrm{a}$ & $0.8 \mathrm{a}$ & $2.2 \mathrm{a}$ & $0.5 \mathrm{c}$ & $0.9 \mathrm{~b}$ \\
\hline$P(1)$ & $11.1 \mathrm{a}$ & $9.4 \mathrm{~b}$ & $16.9 \mathrm{a}$ & $11.0 \mathrm{~b}$ & $2.9 \mathrm{c}$ \\
\hline $\mathrm{Sr}(1)$ & $23.4 \mathrm{a}$ & $16.8 \mathrm{~b}$ & $9.0 \mathrm{~b}$ & $49.0 \mathrm{a}$ & $2.3 \mathrm{c}$ \\
\hline V (2) & $1.4 \mathrm{a}$ & $1.0 \mathrm{~b}$ & $3.2 \mathrm{a}$ & $0.2 \mathrm{~b}$ & $0.2 \mathrm{~b}$ \\
\hline $\mathrm{Zn}(2)$ & $1.4 \mathrm{~b}$ & $3.3 \mathrm{a}$ & $1.8 \mathrm{~b}$ & $4.6 \mathrm{a}$ & $0.7 \mathrm{c}$ \\
\hline
\end{tabular}


Figure 4. 3D visualization of PCA analysis for the variables more discriminant for cultivar in the area of Cetica (Toscana). (A = Arinda, $\mathrm{R}=$ Rossa di Cetica, $\mathrm{S}=$ Sieglinde).

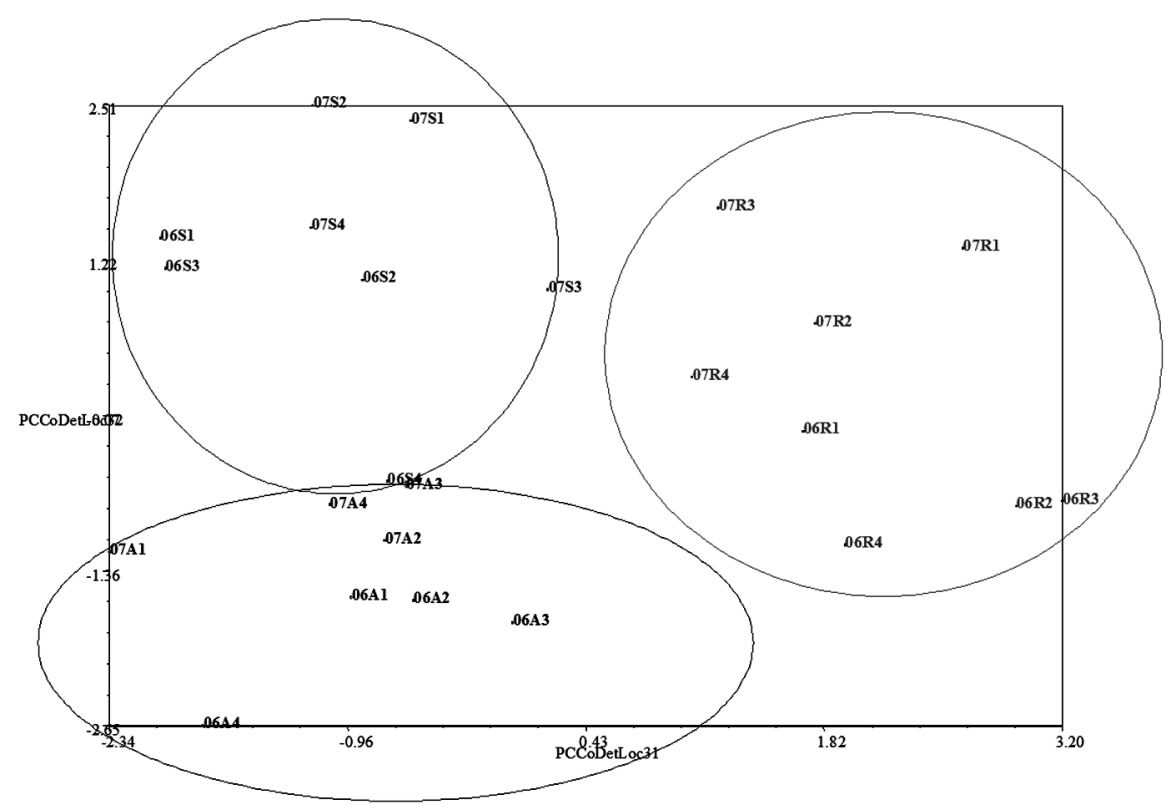

metallic elements (B and P) in the localities of Ugento and Cassibile, while in the soils of Cetica, due to texture (sandy soil) and more intense leaching, those elements were lower. On the other hand, the lower $\mathrm{pH}$ of the soils in Cetica caused a higher mobilization of metallic elements, such as Fe. Other microelements, such as $\mathrm{Cu}, \mathrm{Mn}$ and $\mathrm{Ni}$, were apparently more available in the Ugento soils, even if this higher availability did not affect the content of those elements in the tuber samples collected on the Ugento experimental site. Moreover, the latter microelements were present in higher concentrations in the tubers harvested in Cetica area.

A significant variation in the microelement content was observed in function of the year of experimentation. However, the ratios between the various macro and microelements did not change in the experimental areas.

\section{Discussion}

The results of mineral element determinations, according with previous studies on local food production characterization (Anderson et al., 1999; Di Giacomo et al., 2007; Ariyama et al., 2004; Ariyama et al., 2007), confirmed that the geographic provenance of tuber samples can be discriminated with a high classification percent- age. Multivariate analysis (PCA) applied to the analytical data permitted a clear separation among the groups of provenance. Furthermore, this separation, by inserting in the PCA only those variables more discriminant in function of their determination coefficients for area of experimentation, resulted in a correct classification of $100 \%$. Moreover the discrimination among localities was clear for both of the two vegetal samples, tuber skin and pulp.

The differences between cultivars, even if statistically significant, did not permit the separation into distinct groups. A separation into groups of cultivars, even if with partial overlaps, was only possible within each locality. In particular, only the variety Rossa di Cetica tended to form distinct groups in all areas of experimentation. As a consequence, the utility of the analytical methods applied to this study appeared to be less important for varietal origin verification, for what other screening are today available, such as molecular analysis (Coombs et al., 2004; Ghislain et al., 2004; Feingold et al., 2005; Moisan-Thiery et al., 2005).

Soil analysis indicated a few interesting correlation between soil and tuber mineral element content. On the other hand, the element adsorption from the soil into the potato plant and its accumulation in the tubers seems to be linked more to the ratios between mineral ele- 
ment concentrations instead of the availability of each mineral element in the soil.

In conclusion, the analysis of macro and microelements represents a valid instrument to verify the geographic origin and the typicity of potato food products, especially if supported by correct statistical methods. However, the results of this study also indicated that the power of discrimination can potentially be reduced if the areas of provenance of vegetal samples have similar pedo-climatic characteristics. This is also feasible for cases where the growing area shows a relative high variability in terms of soil composition.

\section{Acknowledgment}

We are indebted with the groups of research coordinated by Professors Vittorio Marzi of the Department of Vegetal Production of the University of Bari and Professor Giovanni Mauromicale of the Department of Agronomic, Agro-chemical and Animal Production Sciences of the University of Catania.

\section{References}

Aires-De-Sousa J. 1996. Verifying wine origin: A neural network approach. American Journal of Enology and Viticulture, 47, 4:410-414.

Anderson K.A., Magnuson B.A., Tschirgi M.L., Smith B. 1999. Determining the geographic origin of potatoes with trace metal analysis using statistical and neural network classifiers. Journal of Agricultural and Food Chemistry, 47:1568-1575.

Ariyama K., Aoyama Y., Mochizuki A., Homura Y., Kadokura M., Yasui A. 2007. Determination of the geographic origin of onions between three main production areas in Japan and other countries by mineral composition. Journal of Agricultural and Food Chemistry, 55:347-354.
Ariyama K., Horita H., Yasui A. 2004. Chemometric techniques on inorganic elements composition for the determination of the geographic origin of Welsh onions. Analytical Sciences 20, 5:871-878.

Coombs J.J., Frank L.M., Douches D.S. 2004. An Applied Fingerprinting System for Cultivated Potato Using Simple Sequence Repeats. American Journal of Potato Research, 81:243-250.

Di Giacomo F., Del Signore A., Giaccio M. 2007. Determining the geographic origin of potatoes using mineral and trace element content. Journal of Agricultural and Food Chemistry, 55:860-866.

Feingold S., Lloyd J., Norero N., Bonierbale M., Lorenzen J. 2005. Mapping and characterization of new EST-derived microsatellites for potato (Solanum tuberosum L.). Theoretical and Applied Genetics, 111:456-466.

Ferland G., Sadowski J. 1992. Vitamin K1 (phylloquinone) content of edible oils: effects of heating and light exposure. Journal of Agricultural and Food Chemistry, 40:1867-1873.

Ghislain M., Spooner D.M., Rodríguez F., Villamón F., Núñez J., Vásquez C., Waugh R., Bonierbale M. 2004. Selection of highly informative and user-friendly microsatellites (SSRs) for genotyping of cultivated potato. Theoretical and applied Genetics, 108:881890.

Moisan-Thiery M., Marhadour S., Kerlan M. C., Dessenne N., Perramant M., Gokelaere T., Le Hingrat Y. 2005. Potato cultivar identification using simple sequence repeats markers (SSR). Potato Research, 48, 3-4:191-200.

Padín P.M., Peña R.M., García S., Iglesias R., Barro S., Herrero C. 2001. Characterization of Galician (N.W. Spain) quality brand potatoes: a comparison study of several pattern recognition techniques. Analyst, 126:97-103.

Parcerisa J., Rafecas M., Castellote A. I., Codony R., Farran A., Garcia J., Lopez A., Romero A., Boatella J. 1994. Influence of variety and geographical origin on the lipid fraction of hazelnuts (Corylus avellana L.) from Spain (2) Triglyceride composition. Food Chemestry, 50:245-249. 